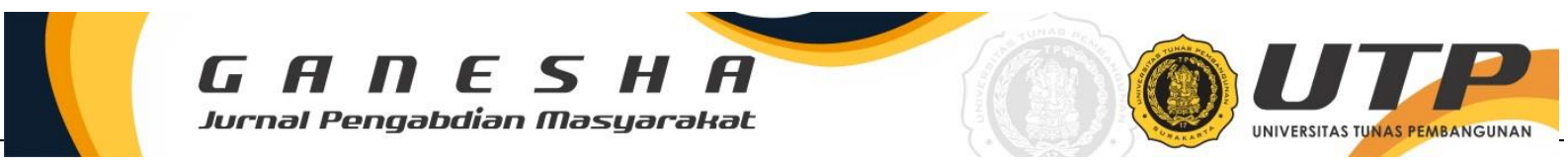

\title{
PENDAMPINGAN PERENCANAAN PEKERJAAN JALAN LINGKUNGAN DI KELURAHAN JAYENGAN KECAMATAN SERENGAN KOTA SURAKARTA
}

\author{
Teguh Yuono*1, Erni Mulyandari ${ }^{2}$ \\ ${ }^{1,2}$ Universitas Tunas Pembangunan Surakarta \\ Email Korespondensi: teguh.yuono@lecture.utp.ac.id
}

\begin{abstract}
Abstrak
Kelurahan Jayengan merupakan salah satu kelurahan di wilayah Kecamatan Serengan, Kota Surakarta, Jawa Tengah. Kelurahan tersebut memiliki tingkat kepadatan 136,31 orang/Ha. Seiring dengan bertambahnya kepadatan penduduk maka pembangunan infrastruktur juga harus ditingkatkan. Pembangunan yang dimaksud salah satunya adalah pembangunan jalan lingkungan. Pembangunan jalan di beberapa titik lokasi Kelurahan Jayengan dianggap perlu karena kondisi eksisting jalan telah banyak yang rusak dan ketika hujan menyebabkan genangan yang secara tidak langsung membuat pengguna jalan menjadi tidak nyaman. Selain itu kontruksi jalan yang ada dianggap tidak memenuhi standar yang berlaku sehingga perlu adanya pendampingan dalam proses perencanaan jalan lingkungan guna meminimalisir kegagalan fungsional. Tahapan yang dilakukan pada pendampingan kali ini meliputi tahap persiapan dan tahap pelaksanaan. Pada kegiatan persiapan dilakukan diskusi dan koordinasi dengan perangkat kelurahan terkait guna memberikan masukan yang bersifat membangun untuk kegiatan ini sedangkan pada tahap pelaksanaan dilakukan pengukuran sampai dengan penggambaran detail desain guna memperkirakan besarnya anggaran biaya untuk pekerjaan jalan lingkungan di Kelurahan Jayengan. Berdasarkan hasil pendampingan dapat diketahui bahwa besarnya dana untuk pekerjaan jalan lingkungan di Kelurahan Jayengan adalah sebesar Rp 157.100.000,00. Hasil analisa biaya tersebut untuk selanjutnya dapat digunakan sebagai dasar dalam pelaksanaan pekerjaan konstruksi.
\end{abstract}

Kata kunci: Jayegan, Jalan, Anggaran Biaya

\begin{abstract}
Jayengan is one of the sub-districts in the Serengan District, Surakarta City, Central Java. The sub-district has a density level of 136.31 people/ha. As population density increases, infrastructure development must also be increased. One of the developments referred to is the construction of environmental roads. Road construction at several locations in the Jayengan Village is deemed necessary because the existing conditions of the road have been damaged a lot and when it rains it causes inundation which indirectly makes road users uncomfortable. Also, the existing road construction is considered not meeting the applicable standards so that assistance is needed in the environmental road planning process to minimize functional failure. The stages carried out in this mentoring include the preparation stage and the implementation stage. In the preparatory activities, discussions, and coordination with related village officials were carried out to provide constructive input for this activity, while at the implementation stage measurements were carried out up to a detailed design description to estimate the amount of the budget for environmental road works in Jayengan Village. Based on the results of the assistance, it can be seen that the amount of funds for environmental road works in Jayengan Village is Rp 157.100.000,00. The results of the cost analysis can then be used as a basis for the implementation of construction work.
\end{abstract}

Keywords: Jayengan, Road, Cost Analysis

\section{PENDAHULUAN}

Kelurahan Jayengan terletak di Kecamatan Serengan Kota Surakarta. Kelurahan Jayengan merupakan kelurahan dengan luasan terkecil di Kecamatan Serengan yaitu sekitar 29,30 Ha. Menurut BPS di Kecamatan Serengan dalam Angka 2019, pada tahun 2018 Kelurahan Jayengan memiliki jumlah penduduk 3.944 orang (1.915 pria dan 2.079 wanita) dengan luas wilayah 29,30 Ha sehingga memiliki tingkat kepadatan berkisar 136,31 orang/Ha. Seiring dengan bertambahnya kepadatan penduduk maka pembangunan infrastruktur juga 
harus ditingkatkan. Pembangunan yang dimaksud salah satunya adalah pembangunan jalan lingkungan.

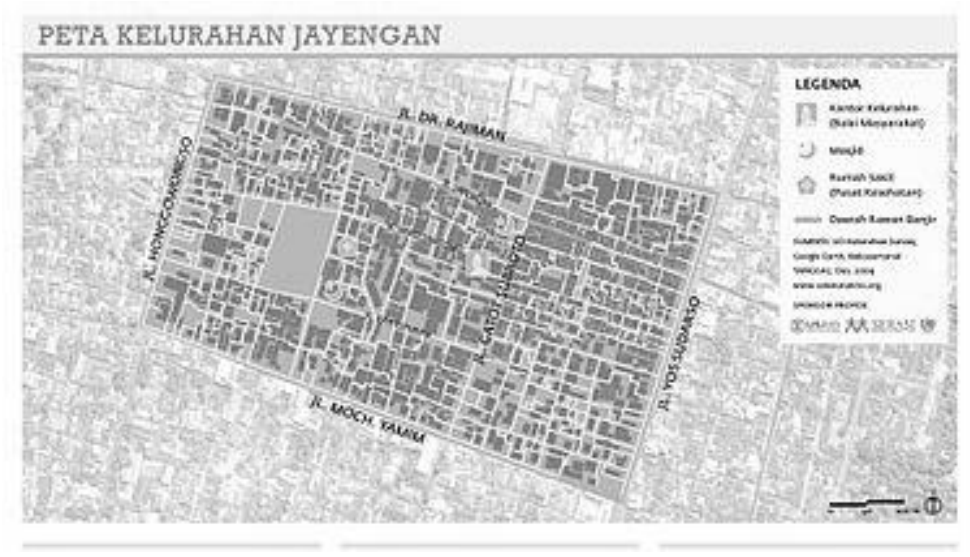

Gambar 1. Peta Kelurahan Jayengan

(Sumber: id.wikipedia.org)

Pembangunan jalan di beberapa titik lokasi Kelurahan Jayengan dianggap perlu karena kondisinya telah banyak yang rusak dan ketika hujan menyebabkan genangan yang secara tidak langsung membuat pengguna jalan menjadi tidak nyaman. Selain itu konstruksi jalan di lokasi kegiatan tidak seragam antara satu dengan yang lain. Terkadang ada yang menggunakan konstruksi beton dan bahkan masih ada yang menggunakan paving tanaman yang tidak sesuai untuk beban lalu lintas di atasnya. Tim pengabdian masyarakat berusaha melakukan diskusi dengan perangkat kelurahan guna memperoleh data mengenai kondisi dan harapan perencanaan jalan lingkungan tersebut di masa yang akan datang. Ada beberapa point informasi yang diperoleh diantaranya konstruksi jalan banyak yang mengalami kerusakan sehingga ketika musim penghujan menyebabkan terjadinya genangan selain itu akibat kerusakan menyebabkan warga yang melewati jalan tersebut menjadi tidak nyaman. Adapun kendala dari perangkat kelurahan yaitu terkait dengan solusi kedepan dan metode yang harus dikerjakan guna perbaikan jalan lingkungan tersebut. Oleh karena itu perlu adanya pendampingan dalam proses perencanaan jalan lingkungan guna meminimalisir kegagalan fungsional.

\section{METODE}

Pelaksanaan pengabdian kepada masyarakat dilaksanakan dengan 2 tahapan yaitu tahap persiapan dan tahap pelaksanaan. Pada tahap persiapan, dilakukan kegiatan diskusi dengan perangkat kelurahan di Kelurahan Jayengan tentang rencana pelaksanaan pengabdian masyarakat oleh tim dosen. Berdasarkan hasil diskusi tersebut diharapkan akan diperoleh informasi secara benar dan akurat. Diskusi tersebut juga berguna untuk menentukan langkah berikutnya demi terwujudnya kondisi yang diharapkan. Setelah diskusi dilakukan maka akan segera direncanakan langkah-langkah dalam pengambilan data di lapangan bersama dengan perangkat kelurahan terkait otoritas wilayah berada di perangkat kelurahan Jayengan. Posisi tim pengabdian masyarakat (dosen) hanya sebagai konsultan yang tidak mempunyai kewenangan memutuskan. Otoritas tim pengabdian masyarakat (dosen) hanya memberikan saran dan usulan yang bersifat membangun dalam koridor rasional dan terukur.

Pada tahap pelaksanaan, dilakukan setidaknya sembilan item pekerjaan yaitu:

1) Melakukan kompilasi data pengukuran, dokumentasi foto, dan lain-lain sebagai bahan untuk proses analisis. 
2) Melakukan analisis tapak terhadap kondisi tapak lokasi jalan eksisting di Kelurahan Jayengan.

3) Melakukan analisis ruang yang sesuai dengan kebutuhan.

4) Membuat gambar pra-desain berupa gambar site-plan, denah, dan potongan.

5) Dari bahan pra-desain yang telah disusun, dilakukan diskusi dengan semua tim dan calon pengguna untuk mendapatkan masukan dan saran untuk perbaikan pra-desain.

6) Setelah mendapat persetujuan gambar pra-desain maka dibuat perhitungan struktur gambar detailnya untuk gambar pelaksanaan konstruksi.

7) Penyusunan gambar detail untuk pelaksanaan konstruksi.

8) Penyusunan analisa yang diperlukan sebagai pendukung.

9) Penyusunan perkiraan rencana anggaran biayanya (RAB).

Kegiatan pelaksanaan pengabdian ini harus diimbangi dengan paritisipasi dari perangkat kelurahan dan masyarakat Kelurahan Jayengan. Adapun perannya yaitu sebagai tempat bertukar pendapat (diskusi) dan sebagai tim pelaksana dalam melakukan peningkatan jalan lingkungan berupa pembangunan jalan paving.

\section{HASIL DAN PEMBAHASAN}

Survei pendahuluan merupakan kegiatan untuk mendapatkan informasi dan data awal yang diperlukan di lokasi pengabdian yang nantinya akan berguna untuk analisis lebih lanjut. Survei pendahuluan untuk pengabdian ini harus melalui beberapa tahapan seperti tahap perijinan, survei lokasi, dan diskusi awal.

Pada tahap perijinan, tim pengabdian akan menyerahkan surat tugas ke perangkat kelurahan Jayengan. Kemudian dilanjutkan dengan melakukan survei lokasi dan pengukuran jalan seperti pada Gambar 2. Berdasarkan hasil survei awal dapat diketahui bahwa jalan lingkungan banyak yang mengalami kerusakan yang dapat dilihat seperti pada Gambar 3 dan Gambar 4. Setelah itu dilakukan diskusi awal oleh tim pengabdian dengan salah satu perangkat kelurahan saat berkunjung ke lapangan. Berdasarkan data dari diskusi awal dapat diketahui terdapat beberapa masalah yang ada di lapangan mulai dari paving lama banyak yang rusak sehingga menyebabkan terjadinya genangan saat hujan turun, mutu paving yang tidak standar untuk akses kendaraan pribadi, dan kondisi aspal jalan banyak yang retak.

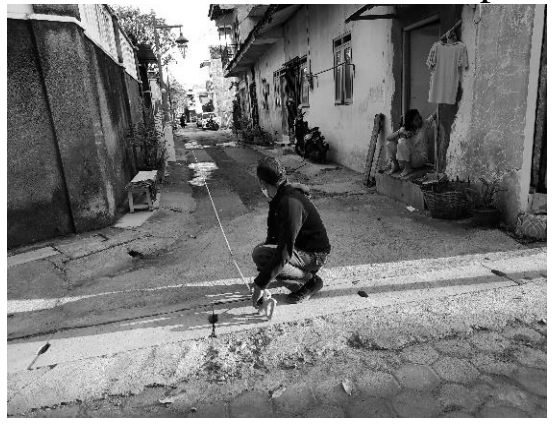

(a)

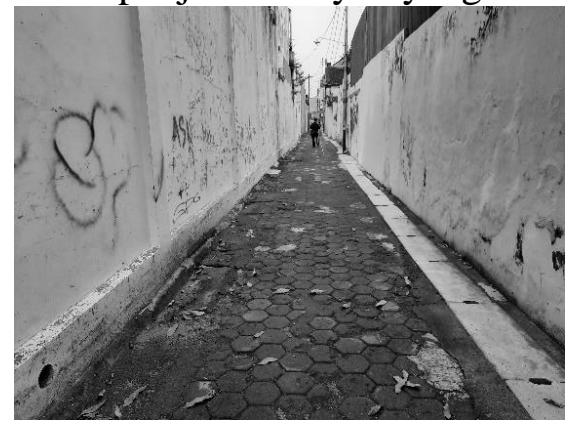

(b)

Gambar 2. Survei Lokasi (a) Pengukuran Panjang Jalan (b) Kondisi Eksisting Jalan Paving 

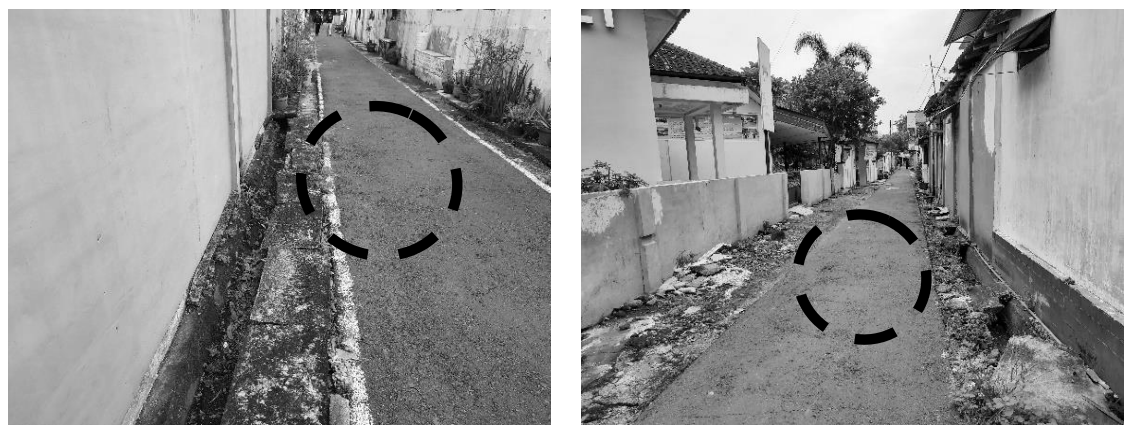

Gambar 3. Kerusakan Aspal Jalan
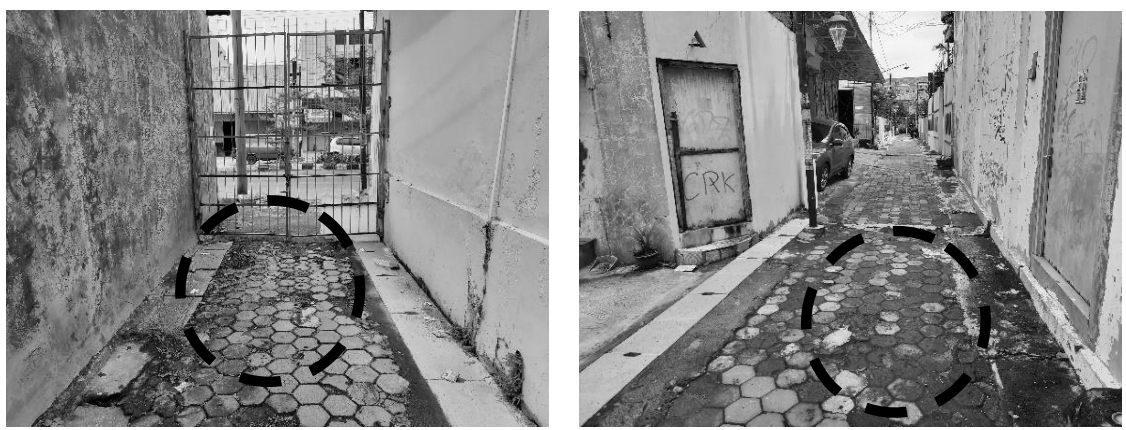

Gambar 4. Kerusakan Paving Jalan

Berdasarkan survei pendahuluan maka telah dilakukan beberapa kegiatan seperti melakukan kompilasi data pengukuran dan foto dokumentasi sebagai bahan untuk proses analisis, melakukan analisis tapak terhadap kondisi tapak lokasi jalan eksisting di Kelurahan Jayengan, melakukan analisis ruang yang sesuai dengan kebutuhan, membuat gambar pradesain berupa gambar site-plan, denah, dan potongan, dari bahan pra-desain yang telah disusun, akan dilakukan diskusi dengan perangkat kelurahan dan warga untuk mendapatkan masukan dan saran untuk perbaikan pra-desain, setelah mendapat persetujuan gambar pradesain maka dibuat perhitungan struktur gambar detailnya untuk gambar pelaksanaan konstruksi, menyusun gambar detail untuk pelaksanaan konstruksi, melakukan analisis pendukung, dan memperkirakan rencana anggaran biayanya (RAB).

Adapun hasil perencanaan pekerjaan jalan lingkungan di Kelurahan Jayengan Kecamatan Serengan Kota Surakarta dapat dilihat seperti pada Gambar 5 sampai dengan Gambar 7. Sedangkan untuk detail potongan dapat dilihat seperti pada Gambar 8.

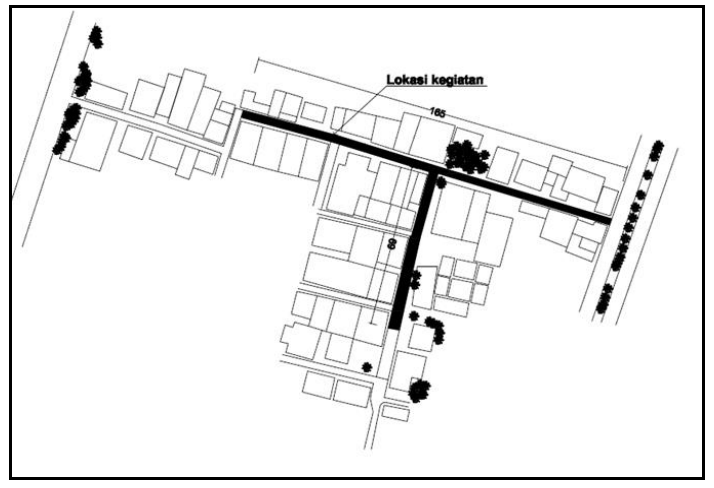

Gambar 5. Site Plan Pekerjaan Jalan Paving 


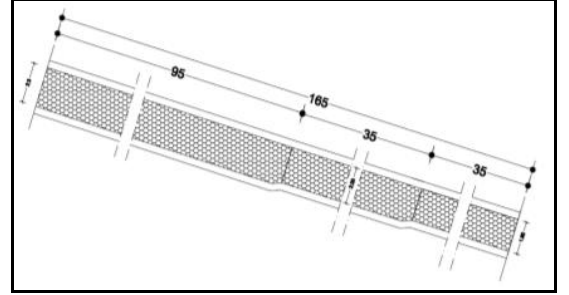

(a)

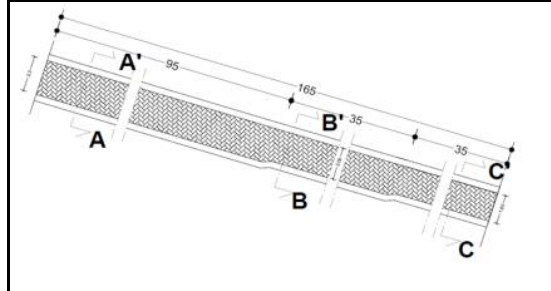

(b)

Gambar 6. Denah Jalan Paving Ruas 1 (a) Eksisting (b) Rencana Perbaikan

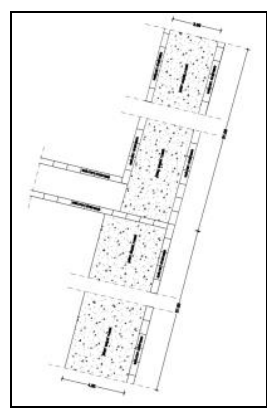

(a)

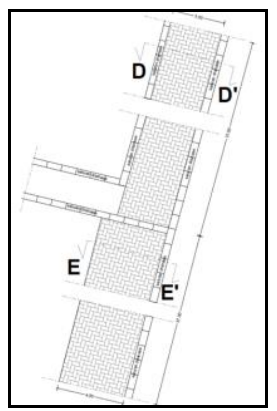

(b)

Gambar 7. Denah Jalan Paving Ruas 2 (a) Eksisting (b) Rencana Perbaikan

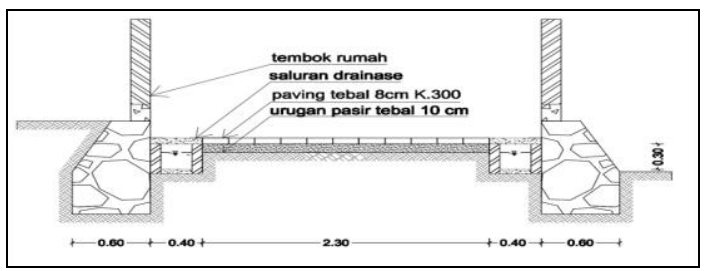

(a)

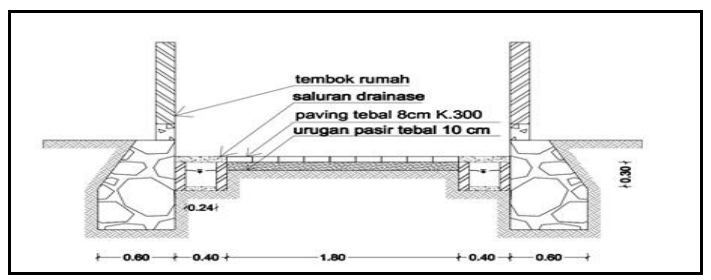

(c)

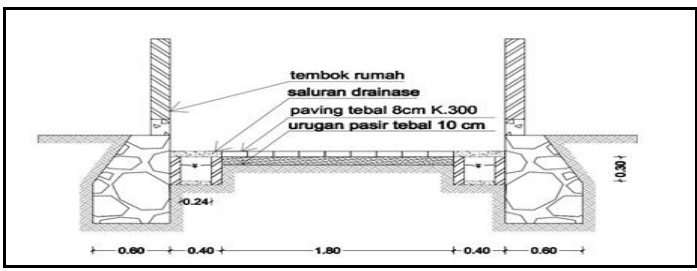

(b)

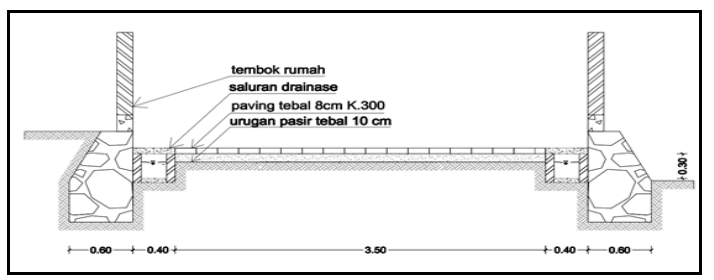

(d)

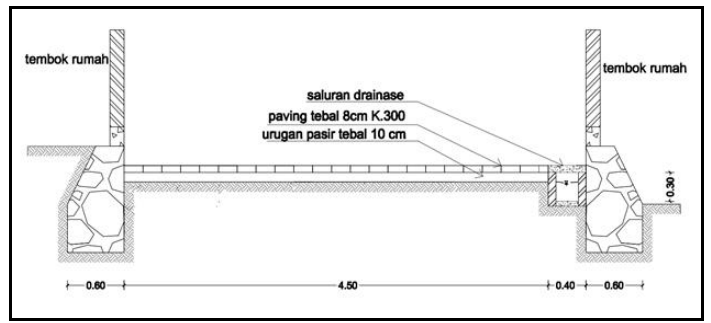

(e)

Gambar 8. Detail Potongan (a) Potongan A - A' (b) Potongan B - B' (c) Potongan C - C' (d) Potongan D - D' (e) Potongan E - E' 
Berdasarkan gambar denah dan detail potongan tersebut di atas, maka sub item yang direncanakan bersama dengan aparat kelurahan Jayengan dapat dilihat seperti pada Tabel 1.

Tabel 1. Rencana Anggaran Biaya

\begin{tabular}{|c|c|c|c|c|c|}
\hline No. & Uraian Pekerjaan & Volume & Satuan & Harga Satuan & Jumlah \\
\hline $\mathbf{A}$ & Pekerjaan Persiapan & & & & \\
\hline 1 & Pengukuran dan Pematokan & 5,00 & $\mathrm{~m}$ & $130.808,60$ & $654.043,00$ \\
\hline 2 & Air Kerja & 3,00 & Minggu & $100.000,00$ & $300.000,00$ \\
\hline \multirow[t]{2}{*}{3} & Pemasangan Papan Proyek & 1,00 & bh & $250.000,00$ & $250.000,00$ \\
\hline & & & Jumlah & $\mathbf{A}$ & $1.204 .043,00$ \\
\hline B & \multicolumn{5}{|c|}{ Pekerjaan Pembanguan Jalan Paving (Panjang 165 m) Ruas 1} \\
\hline 1 & Bongkar Paving Lama dan Pembersihan & 351,50 & $\mathrm{~m}^{2}$ & $11.250,00$ & $3.954 .375,00$ \\
\hline 2 & Buang Bongkaran & 24,61 & $\mathrm{~m}^{3}$ & $50.000,00$ & $1.230 .250,00$ \\
\hline 3 & Pengurugan Pasir Bawah Paving & 35,15 & $\mathrm{~m}^{3}$ & $201.290,00$ & 7.075.343,50 \\
\hline 4 & Perataan dan Pemadatan Tanah & 35,15 & $\mathrm{~m}^{3}$ & $38.450,00$ & $1.351 .517,50$ \\
\hline \multirow[t]{2}{*}{5} & Pemasangan Paving Kotak Tebal 8cm K 300 & 351,50 & $\mathrm{~m}^{2}$ & $219.063,00$ & $77.000 .644,50$ \\
\hline & & & Jumlah & B & $90.612 .130,50$ \\
\hline $\mathbf{C}$ & \multicolumn{5}{|c|}{ Pekerjaan Pembanguan Jalan Paving (Panjang 66,1 m) Ruas 2} \\
\hline 1 & Bongkar Gundukan Beton Tepi Saluran & 2,27 & $\mathrm{~m}^{3}$ & $276.840,00$ & $628.980,48$ \\
\hline 2 & Buang Bongkaran & 2,27 & $\mathrm{~m}^{3}$ & $50.000,00$ & $113.600,00$ \\
\hline 3 & Pengurugan Pasir Bawah Paving & 26,60 & $\mathrm{~m}^{3}$ & $201.290,00$ & $5.353 .307,55$ \\
\hline 4 & Perataan dan Pemadatan Tanah & 26,60 & $\mathrm{~m}^{3}$ & $38.450,00$ & $1.022 .577,75$ \\
\hline \multirow[t]{4}{*}{5} & Pemasangan Paving Kotak Tebal 8cm K 300 & 265,95 & $\mathrm{~m}^{2}$ & $219.063,00$ & $58.259 .804,85$ \\
\hline & & & Jumlah & C & $65.378 .270,63$ \\
\hline & Total Biaya Pekerjaan & & & & $157.194 .444,13$ \\
\hline & Pembulatan & & & & $157.100 .000,00$ \\
\hline
\end{tabular}

\section{KESIMPULAN}

Tim pengabdian kepada masyarakat telah melaksanakan pendampingan dalam melakukan perencanaan pekerjaan jalan lingkungan di Kelurahan Jayegan Kecamatan Serengan Kota Surakarta. Untuk kegiatan ini dapat diketahui besarnya rencana anggaran biaya untuk kegiatan ini adalah sebesar Rp 157.100.000,00.

\section{UCAPAN TERIMA KASIH}

Penulis mengucapkan terima kasih kepada aparat kelurahan Jayengan yang telah memberikan kesempatan untuk melakukan pengabdian kepada masyarakat di lokasi terkait.

\section{DAFTAR PUSTAKA}

Anonim. (1990). SK. SNI. T-04-1990-F. Tata Cara Pemasangan Blok Beton Terkunci Untuk Permukaan Jalan. DPU. 
ASTM International, Standard Practice for Roads and Parking Lots Pavement Condition Index Surveys, Designation: D 6433 - 07

Badan Pusat Statistik. (2019). Kecamatan Serengan Dalam Angka 2019. Badan Pusat Statistik.

Direktorat Jenderal Bina Marga. (1997). Manual Kapasitas Jalan Indonesia (MKJI). Jakarta: Departemen Pekerjaan Umum.

Direktorat Jenderal Bina Marga. (2004). Survei Invetarisasi Geometri Jalan Perkotaan, Jakarta: Departemen Pekerjaan Umum.

Direktorat Pembinaan Jalan Kota. (1990). Tata Cara Penyusunan Pemeliharaan Jalan Kota (No. 018/T/BNKT/1990). Jakarta: Direktorat Jendral Bina Marga Departemen PU.

Hardiyatmo, H.C. (2007). Pemeliharaan Jalan Raya. Yogyakarta: Gadjah Mada University Press.

Mukomuko, Ir.J.A. (1985). Dasar Penyusunan Anggaran Biaya Bangunan. Jakarta: Gaya Media Pratama.

Jayengan, Serengan, Surakarta https://id.wikipedia.org/wiki/Jayengan,_Serengan,_Surakarta Standar Nasional Indonesia. Geometrik Jalan Perkotaan, RSNI T-14-2014

Tjokrodimuljo, K. (1996). Teknologi Beton. Jurusan Teknik Sipil. Jogjakarta: Teknik Sipil Universitas Gadjah Mada. 